\title{
An Investigation of EFL Teachers' Beliefs and Practices of Learner Autonomy
}

\author{
Dr. Maha Alhaysony \\ Department of English Language, College of Arts, University of Ha'il, Saudi Arabia
}

\begin{abstract}
This paper aimed to explore in an elaborative way what "learner autonomy" means to 77 (40 males, 37 females) EFL teachers at AljoufUniversity in Saudi Arabia. The purpose of the study is to reveal different perceptions of learner autonomy taken from the classroom experiences of the teachers. A questionnaire and semi-structured interviews were used to collect data. Quantitative data of the study were analysed by calculating descriptive statistics, including frequencies, means and standard deviations. Qualitative data of the study were categorized in terms of research questions and used for answering the questions in collaboration with the quantitative data in the discussion of the results. The findings revealed that EFL teachers were mostly positive about learner autonomy and aware of its importance for language learning. In relation to their teaching, though, the teachers were much less positive about the extent to which autonomy can be productively promoted with their students. They provide opportunities for learners to develop autonomy both inside and outside the classroom; however, most students lack the capacity and desire to take advantage of these opportunities. It is hoped that these findings partly contribute to the literature regarding the promotion of learner autonomy in EFL contexts.
\end{abstract}

Keywords: learner autonomy, teachers' beliefs, autonomous learning, EFL teachers, Classroom practices

\section{INTRODUCTION}

Since the 1980s, teachers and researchers have begun to focus on learner autonomy. This attention started when Henri Holec defined the concept of learner autonomy as the capability to take charge of one's own learning (Benson, 2006). The traditional view that the teacher is the person who has the authority as a source of knowledge and decides what and how to learn has been gradually changed. Thus, in recent years, the term "learner autonomy" has been considered to be a key area of research in foreign/second language. Thus, learner autonomy has become one of the intriguing issues in the field of second language acquisition. In addition, it has been seen as a way to authorize learners and make them responsible for their own learning. Moreover, Smith $(2008$, p. 2) stated that "learners have the power and right to learn for themselves". Such a notion is seen as a vital aspect of learner autonomy.

Murphy (2008) pointed out that it is broadly agreed that language learners can profit from autonomous learning. Further, learner autonomy, according to Littlejohn, (1985, p. 258), relies on the idea that it is a student-centred method, which means if the students are involved in the decisionmaking process regarding their own language ability, "they are likely to be more enthusiastic about learning". Additionally, the process of learning can be regarded as a focus and purposeful for them (Camilleri, 1997; Chan, 2001, 2003). Further, in order to contribute to the development of learner autonomy, teachers should be involved in this change and process. However, it is a fact that language teachers without any training in autonomy-oriented methods might experience difficulties in creating such an environment in the classroom. Dam (2003, p. 135), stated that "it is largely the teachers" responsibility to develop learner autonomy". Further, Little (1995, p. 175) mentioned that learner autonomy relies on teacher autonomy in two senses: a) "It is unreasonable to expect teachers to foster the growth of autonomy in their learners if they themselves do not know what it is to be an autonomous learner. b) In determining the initiatives they take in their classrooms, teachers must be able to apply to their teaching those same reflective and self-managing processes that they apply to their learning.". Thus, learner autonomy depends on teacher autonomy because both are fully keen in achieving the optimal effectiveness of language teaching and learning. Accordingly, they lead the learners to accept responsibility for their own learning, guiding them to be reflectively involved in planning, monitoring, developing and evaluating their learning. 


\section{LITERATURE REVIEW}

\subsection{Definitions of Learner Autonomy}

Learner autonomy has attracted ESL/EFL teachers and researchers and the concept of learner autonomy has got their attention. Thus, several definitions have been offered in learning/teaching research. However, they followed Holec's classic definition mentioned earlier. In this section, we will give a summary of some definitions in this area. Some commonly used definitions of learner autonomy are shown as follows in Table 1:

Table1. Different definitions of learner autonomy

\begin{tabular}{|l|l|}
\hline Source & Definition \\
\hline Trim (1976, p.37) & $\begin{array}{l}\text { "an adaptive ability allowing learners to develop supportive structures within } \\
\text { themselves rather than to have them erected around them". }\end{array}$ \\
\hline Dickinson (1987, p.27) & $\begin{array}{l}\text { "a mode of learning; one in which the individual is responsible for all the } \\
\text { decisions connected with her learning, and undertakes the implementation of } \\
\text { these decisions". }\end{array}$ \\
\hline Dam et al. (1990,p. 102) & $\begin{array}{l}\text { 'a capacity and willingness to act independently and cooperation with others, as } \\
\text { a social responsible person". }\end{array}$ \\
\hline Little (1991,p.4) & $\begin{array}{l}\text { "a capacity for detachment, critical reflection, decision making and } \\
\text { independent action". }\end{array}$ \\
\hline "the individual has the right to be free to exercise his or her own choices". \\
\hline Dickinson(1994,p.167) & $\begin{array}{l}\text { "an attitude towards learning in which the learner is prepared to take, or does } \\
\text { take, responsibility for his own learning". }\end{array}$ \\
\hline Cotterall (1995, p.195) & $\begin{array}{l}\text { "the extent to which learners demonstrate the ability to use a set of tactics for } \\
\text { taking control of their learning". }\end{array}$ \\
\hline Rieire (1996, p. 332) & $\begin{array}{l}\text { "the learners' capacity and freedom to construct and reconstruct the taught } \\
\text { knowledge". }\end{array}$ \\
\hline Hedge (2000, p.410) & $\begin{array}{l}\text { "the ability of the learner to take responsibility for his or her learning and to } \\
\text { plan, organize, and monitor the learning process independently of the teacher". }\end{array}$ \\
\hline "the capacity to take control of one's own learning". \\
\hline Benson (2001, p.47) & "one's ability to decide the laws for oneself". \\
\hline
\end{tabular}

Thus, it is obvious that many terms have been used to refer to learner autonomy, such as "ability, capacity, take responsibility, take control, learner's demonstration, attitude, willingness, mode of learning". Furthermore, according to Benson and Voller (1997), the term "learner autonomy" is considered to be used in at least the following five modes: "situations in which learners entirely study on their own; a set of skills which can be learned and applied in the self-directed learning; an inborn capacity which is suppressed by institutional education; the exercise of learners' responsibility for their own learning; and the right of learners to determine the direction of their own learning" (p.2).

\subsection{The Teacher's Role}

The learning process not only involves learners but also an interactional relationship between learners and teachers. According to Benson (2008), a teacher has a vital role in the development of learner autonomy. Barillaro (2011) argued that teachers have to create an environment that supports learner autonomy and raise their awareness of independent learning. Additionally, they must clarify their perceptions about teaching and learner autonomy. Their role is regarded as an organizer and analyst as they help learners to take responsibility by setting their own goals, planning practice opportunities and assessing their progress (Al Asmari, 2013, p. 1). Zhuang (2010) pointed out that teachers do not only have the role of knowledge transferor, but they also have the roles of consultant and facilitator who provide psychological, social and technical support for their students. Yunus and Arshad (2015) argued that in order to develop learner autonomy, teachers have to provide necessary assistance to help learners to be more independent inside and outside the classroom. Additionally, the teacher's presence is very important where communicative language teaching can be practiced in order to develop learner autonomy through group work that would contribute to achieving learners' shared aims and gradually build the sense of interdependence among them (Little, 1991; Littlewood, 1999; Benson, 2001; and Yildirim, 2008).

Camilleri (1999), pointed out that the most important role for the teacher is the awareness of self. Thus, the teacher's characteristics are to be aware of his/her own personal influence on the learning process, understand teaching and be skilled in management. This means that the teacher works as a 
manager who is able to map out the most probable paths available to the learners and also the consequences of following any particular path. Additionally, a teacher could be regarded as a resource person who optimizes learning conditions by helping students be aware of all alternatives and techniques. Finally, a teacher is a counsellor who is able to accompany individuals' learning process and respond meaningfully to learning difficulties (Camilleri, 1999, p.38). Further, Joshi (2011) stated that a teacher is considered to be a facilitator, an organizer, a resource person providing learners with feedback and encouragement, and a creator of learning environments. He added that teachers work as guides, co-operators and motivators rather than as an authority.

According to Nunan (1997, p. 201), teachers can encourage learner autonomy in the language classroom by:

1. Integrating language content and learning process through learner strategy training.

2. Incorporating reflective lessons into teaching.

3. Drawing up learner contracts.

4. Learner diaries.

Little et al. (2007) conclude that there are three areas regarding the teacher's role in autonomous learning: a) they should involve their students in their own learning; b) they have to get their students to reflect about learning and about the target language; and c) they should engage their students in appropriate target language use. In short, these all show that teachers have an important role in the learning process of students in an autonomous learning environment, and in developing responsibility on the part of the learners.

\subsection{Previous Studies on Teachers' Beliefs about Learner Autonomy}

Numerous studies have been conducted about learner autonomy, but few studies have examined teachers' perceptions and beliefs. In other words, teachers' perspectives toward understanding learner autonomy seem to be neglected. Thus, further research on teachers' understanding and beliefs regarding learner autonomy is vital as teachers are the individuals who directly deal with the learners.

Camilleri (1999) conducted a study on 328 teachers from different European areas (the Netherlands, Belarus, Poland, Malta, Estonia and Slovenia). The results showed that teachers often have a willingness to change and develop their teaching practice. They believed strongly that students should be involved in decisions about a number of learning strategies, such as determining and establishing the objectives of the course and selecting course content. In addition, Camilleri (2007) replicated her study in Malta on 48 respondents (students, teachers and practicing teachers of modern languages). The findings revealed that teachers had a positive attitude toward learner autonomy. Moreover, AlShaqsi (2009) conducted a study on 120 teachers of English in Oman, which showed that teachers had defined learner autonomy as independent learning, self-evaluation, taking responsibility and cooperating. In addition, they evaluated their students positively on all of the indicators of learner autonomy.

Further, teachers believed that their students had the ability of practicing learning autonomy. This finding was consistent with the study of Balcikanli (2010) on 112 teachers of English in Turkey. In the study of Barillaro (2011), who investigated teachers' perceptions about learner autonomy in language learning, the results showed that teachers considered themselves responsible for decisions about teaching and language-related issues inside the classroom. Also, they held positive opinions about autonomous learning activities both inside and outside the classrooms. This concurs with the study of Joshi (2011), who also found that teachers regarded their role in the learning process as facilitators and that autonomy is considered to be the basis of both higher proficiency and performance as well as very useful in the process of learning. Nakata (2011) conducted a study investigating EFL teachers' beliefs and practices regarding learner autonomy as well as teachers' professional autonomy. The findings revealed institutional inflexibility and entrance-exam constraints as the most prominent factors which hindered Japanese EFL teachers from implementing autonomy promoting strategies. Further, Nakata argued that in order to make autonomy "a reality" in Japanese EFL classrooms, teachers have to know and realize the importance of promoting learner autonomy and the required strategies. 
Recently, Borg and Al-Busaidi (2012) examined language teachers' opinions about autonomous learning. They found that teachers have a positive outlook toward the concept of learner autonomy and that it is quite useful for language learners. Additionally, the teachers were motivated to make it their focus in the process of teaching. They summarized it as a set of capabilities and skills that learners have to master in order to learn independently. The researchers added that teachers always subordinate autonomy with possibilities for independent learning, irrespective of whether learners were involved with these. Al Asmari (2013) conducted a study on 60 teachers (males and females), teaching English at Taif University English Language Centre (TUELC). His aim was to investigate the present status of learner autonomy, teaching practices and strategies for developing learning autonomy in an English classroom. The results showed that both male and female teachers agreed with the involvement of learners in making decisions about the process of learning. Additionally, he found that there was a great tendency for autonomous learning among teachers, and they thought that the autonomous learner has an active and positive role in the learning process. Duong (2014) examined EFL teachers' perceptions of learner autonomy and their practices in classrooms. The results showed that teachers defined learner autonomy as students' freedom to choose how and what they learn and students' monitoring their own learning process, and while the teachers supported their role in the learning process, it was quite difficult for them to apply it in the classroom. Yunus and Arshad (2015) explored 35 teachers' viewpoints on autonomous language learning, practices and prospects of learner autonomy in their classrooms in Malaysian public secondary schools. The results showed that teachers had very strong positive attitudes toward the implementation of autonomous language learning among students. Najmeh et al. (2015) investigated teachers' practices in promoting learner autonomy in Iranian EFL teachers. The practices of 42 teachers (males and females) were observed, and then 19 teachers were interviewed. The results showed that teachers had positive attitudes toward learner autonomy and they implemented a number of strategies for promoting the autonomy of learners.

Despite the overabundance of research investigating learner autonomy in general, and teachers' perceptions in particular, teachers' perceptions and the practicalities of the notion of learner autonomy may differ according to cultural settings. Unsurprisingly, the differences affect the methods of promoting learner autonomy to language learners as the level of readiness for learner autonomy varies across cultures and educational backgrounds. Therefore, in order to build a design and adapt strategies for endorsing autonomous learning, the current study can bridge the gap by investigating Saudi EFL teachers' perceptions, practices and cognition toward the concept of learner autonomy using multiple methods (questionnaire and interviews).

\section{Research Questions}

Although research in second/foreign language has been conducted investigating a variety of language learning tasks and different issues related to language learning, much additional research must be done with language learning techniques, especially focusing on learner autonomy, which could help students develop their skills in learning language. As the aim of this study is to investigate teachers' perceptions of learner autonomy and their teaching practices, it seeks to find the answers to the following research questions:

1. What does "learner autonomy" mean to English language teachers?

2. To what extent do teachers feel their learners are autonomous?

3. To what extent do teachers say they actually promote learner autonomy?

4. How desirable and feasible do teachers feel it is to promote learner autonomy?

5. What challenges do teachers face in helping their learners become more autonomous?

\section{Methods}

\subsection{Participants}

The participants of this study were 77EFLteachers (40 males, 37 females) teaching English at Aljouf University in Saudi Arabia. The participants were of different nationalities (Arabs, American, British, South African and Australians). 


\subsection{Instruments}

In order to get thorough information and data about autonomous language learning, and teachers' perceptions about learner autonomy, we have used a questionnaire and semi-structured interviews.

\subsubsection{Questionnaire}

The questionnaire was adapted from Borg and Al-Busaidi (2012), but some modifications were made to the questionnaire according to the purpose of the study. The questionnaire was designed to gather information about teachers' beliefs regarding learner autonomy. It has five major sections. The first section was about demographic information. The second section consists of 37 statements rated on a Likert-type scale, with five options to tick - namely "strongly disagree, disagree, unsure, agree, and strongly agree". These statements address 10 constructs as follows:

1. Technical perspectives on learner autonomy.

2. Psychological perspectives on learner autonomy.

3. Social perspectives on learner autonomy.

4. Political perspectives on learner autonomy.

5. The role of the teacher in learner autonomy.

6. The relevance of learner autonomy to diverse cultural contexts.

7. Age and learner autonomy.

8. Proficiency and learner autonomy.

9. The implications of learner autonomy for teaching methodology.

10. The relationship of learner autonomy to effective language learning.

(Borg and Al-Busaidi, 2012, pp. 10)

The third section focuses on teachers' views about the desirability and feasibility of learner involvement in language course decisions (e.g. in setting objectives), and of various learner abilities (e.g. self-evaluation). The fourth section focuses on teachers' beliefs about how autonomous their learners are and on the extent to which they promote autonomy in teaching.

The questionnaires were distributed among a group of 77 teachers, both males and females. The collected questionnaires were analysed to get the results using SPSS 19 to calculate descriptive statistics (for example, frequency counts, means and standard deviations).

\subsubsection{Semi-structured interviews}

Semi-structured interviews were chosen in order to allow an element of flexibility. The purpose of the interviews was to further explore the teachers' answers in the questionnaire and to elicit specific examples from teachers about their responses to some of the issues in the study. In the questionnaire, teachers were also asked if they would like to participate in a follow-up interview and only 31 volunteered (14 males, 17 females). The interviews were conducted within two weeks. Each interview lasted about 20 minutes on average. Females' interviews were conducted face to face in Aljouf University, while males' interviews were done by phone due to the education system whereby males and females are segregated, as I do not have access to the males. All interviews were conducted in English and were audio-recorded with the permission of the interviewees. The researcher used codes to refer to the interviewees in order to protect their identity.

\subsubsection{Data analysis}

The main data include the transcripts made from the interviews. The data were analysed qualitatively through thematic analysis which involves careful reading of the data, identifying key issues and organizing them into broader categories (Guest, 2012).

\section{RESUlTS AND DISCUSSION}

In this section, results obtained from questionnaires and interviews will be presented and discussed under the five research questions. 


\subsection{Teachers' Beliefs and Understanding of Learner Autonomy}

The second part of the questionnaire, which includes 37 items, was employed to examine teachers' overall beliefs regarding learner autonomy. In other words, the answer to the first research question (What does "learner autonomy" mean to English language teachers?) will be presented. The following subsections will be divided according to the 10 constructs discussed earlier in the questionnaire section of the methodology (3.2.1).

\subsubsection{Findings regarding technical perspectives on learner autonomy}

Items 2, 6, 21 and 31 in the second part of the questionnaire explore technical perspectives of learner autonomy. These are the statements which emphasize learning on one's own and developing the technical ability to do so.

Table2. Technical perspectives on learner autonomy

\begin{tabular}{|l|l|l|}
\hline Statement & Mean & SD \\
\hline 2. Independent study in the library is an activity which develops learner autonomy & 4 & .739 \\
\hline 6. Autonomy can develop most effectively through learning outside the classroom. & 3.55 & .876 \\
\hline 31. Out-of-class tasks that require learners to use the internet promote learner autonomy. & 3.50 & .925 \\
\hline 21. Learner autonomy is promoted by independent work in a self-access centre. & 3.44 & .776 \\
\hline
\end{tabular}

As shown in Table 2, the means and standard deviations of teachers' perceptions about technical perspectives on learner autonomy are displayed. The results revealed that the statement "Independent study in the library is an activity which develops learner autonomy" was the one most favoured by teachers with a mean of 4 and standard deviation of .739. This was followed by the statement "Autonomy can develop most effectively through learning outside the classroom" with a mean of 3.55 and standard deviation of .876. In addition, teachers agreed that learners can promote their learning autonomy through using the internet for out-of-class tasks and by independent work in a self-access centre. Thus, the majority of the teachers believe that autonomy can be developed outside the classroom through the activities undertaken by learners on their own and that these activities are effective ways of promoting learner autonomy. This finding is in line with previous studies such as Borg and Al-Busaidi(2012), Duong (2014) and Salimi and Ansari (2015).

\subsubsection{Findings regarding psychological perspectives on learner autonomy}

The teachers' responses for items 11,29,32, 33 and 37, concerning the psychological perspectives on learner autonomy, will be presented in this subsection and is presented in Table 3 below.

Table3. Psychological perspectives on learner autonomy

\begin{tabular}{|l|l|l|}
\hline Statement & Mean & SD \\
\hline $\begin{array}{l}\text { 11. Confident language learners are more likely to develop autonomy than those who lack } \\
\text { confidence. }\end{array}$ & 4.15 & .867 \\
\hline 29. Learning how to learn is key to developing learner autonomy. & 4.37 & .815 \\
\hline 32. The ability to monitor one's learning is central to learner autonomy. & 4 & .755 \\
\hline $\begin{array}{l}\text { 33. Motivated language learners are more likely to develop learner autonomy than learners who } \\
\text { are not motivated. }\end{array}$ & 4.35 & .962 \\
\hline 37. To become autonomous, learners need to develop the ability to evaluate their own learning. & 4.33 & .837 \\
\hline
\end{tabular}

The statements illustrated in Table 3 focus on the internet psychological capability to self-direct one's own learning, and the development of the attitudes and beliefs that allow learners to take more responsibility for their own learning. The results showed that the majority of the teachers stated their agreement with item 29, "Learning how to learn is key to developing learner autonomy", and item 33, "Motivated language learners are more likely to develop learner autonomy than learners who are not motivated", with means of 4.37 and 4.35 and standard deviations of .815 and .962 , respectively. Similarly, the teachers also think that to become autonomous, learners need to develop the ability to evaluate their own learning, and that confident language learners are more likely to develop autonomy than those who lack confidence-with means of 4.33 and 4.15 and standard deviations of .837 and .867 , respectively. Additionally, most of them agreed with item 32, that "The ability to monitor one's learning is central to learner autonomy".

As can be concluded from the responses, the majority of the teachers believe that confident and motivated language learners can develop autonomy more easily than learners who are not confident enough and are less motivated. Further, they believe that to become autonomous, learners need to 
monitor and evaluate their own learning as well as know how to learn. This was supported by the teachers' answers in the interviews and concurs with previous studies such as Arshed (2015) and Salimi and Ansari (2015).

\subsubsection{Findings regarding social perspectives on learner autonomy}

This subsection sheds light on statements $3,16,19,25$ and 30, which focus on socially facilitated learning and the improvement of the learners on the basis of the skills and strategies needed for effective learning and participation in groups.

Table4. Social perspectives on learner autonomy

\begin{tabular}{|l|l|l|}
\hline Statement & Mean & SD \\
\hline $\begin{array}{l}\text { 3. Learner autonomy is promoted through regular opportunities for learners to complete tasks } \\
\text { alone. }\end{array}$ & 4.15 & .783 \\
\hline $\begin{array}{l}\text { 16. Learner autonomy is promoted through activities which give learners opportunities to learn } \\
\text { from each other. }\end{array}$ & 3.95 & .724 \\
\hline 19. Learner autonomy is promoted by activities that encourage learners to work together. & 3.76 & .845 \\
\hline 25. Co-operative group work activities support the development of learner autonomy. & 3.36 & .866 \\
\hline 30. Learning to work alone is central to the development of learner autonomy. & 3.28 & .759 \\
\hline
\end{tabular}

As illustrated in Table 4, teachers expressed their agreement that learner autonomy can be promoted through regular opportunities for learners to complete tasks alone, activities which give learners opportunities to learn from each other and activities that encourage learners to work together. They also agreed that co-operative group work activities support the development of learner autonomy and that learning to work alone is central to the development of learner autonomy. Thus, the teachers shared the idea that working collaboratively helps promote learner autonomy. Additionally, they believed that learning to work alone is as vital as learning from each other for the development of learner autonomy. This is consistent with Duong (2014).

\subsubsection{Findings regarding political perspectives on learner autonomy}

In this subsection, results will be offered by looking at the items presented in Table 5, which focus on the power to control one's situation and on developing in learners the skills to exercise choice.

Table5. Political perspectives on learner autonomy

\begin{tabular}{|l|l|l|}
\hline Statement & Mean & SD \\
\hline 4. Autonomy means that learners can make choices about how they learn. & 4.77 & .926 \\
\hline 7. Involving learners in decisions about what to learn promotes learner autonomy. & 4.18 & .873 \\
\hline $\begin{array}{l}\text { 14. Learner autonomy is promoted when learners have some choice in the kinds of activities } \\
\text { they do. }\end{array}$ & 3.84 & .675 \\
\hline $\begin{array}{l}\text { 22. Learner autonomy is promoted when learners are free to decide how their learning will be } \\
\text { assessed. }\end{array}$ & 3.56 & .756 \\
\hline 27. Learner autonomy is promoted when learners can choose their own learning materials. & 3.79 & .788 \\
\hline
\end{tabular}

The results in Table 5 revealed that in order to develop learner autonomy, learners have to be involved in the decision-making process during the learning process and also need to be given the chance to decide what to learn and how to learn. It is obvious that the statement "autonomy means that learners can make choices about how they learn" got the highest mean (mean $=4.77$, standard deviation= 926). In addition, the second-highest agreement was regarding the statement that "involving learners in decisions about what to learn promotes learner autonomy", with a mean of 4.18 and standard deviation of .873 . The means of items 14, 22 and 27 were greater than 3, which indicates that teachers also agreed with the role of learners in promoting autonomy. Such findings are consistent with the interview results, as most of the teachers reported their agreement that giving learners opportunities to make decisions about their own learning process is an important factor in promoting learner autonomy. Also, they preferred to involve learners in the decision-making process related to activities which can be done in the classroom, the subjects to be taught and the ways of learning, as well as in assessment and the choice of learning materials. The teachers' responses in the interviews supported such findings.

\subsubsection{Findings regarding the role of the teacher in promoting autonomy}

Teachers' perspectives were elicited about the role of the teacher in promoting learner autonomy. Table 6 presents the means of the teachers' perspectives regarding this issue. 
Table6. The role of the teacher in promoting autonomy

\begin{tabular}{|l|l|l|}
\hline Statement & Mean & SD \\
\hline 35. The teacher has an important role to play in supporting learner autonomy. & 4.63 & .875 \\
\hline 18. Learner autonomy cannot develop without the help of the teacher. & 4.35 & .796 \\
\hline 24. Learner autonomy requires the learner to be totally independent of the teacher. & 3.44 & .983 \\
\hline 8. Learner autonomy means learning without a teacher. & 3.25 & .883 \\
\hline
\end{tabular}

As displayed in Table 6, the mean score ranged from 3.25 to 4.63 , providing a clear indication that teachers have the conception that the teacher has an important role in supporting learner autonomy and there is a need for teacher's help in promoting learner autonomy. Thus, the results reveal that in order to develop autonomy, learners need some independence, yet this does not mean being totally independent from the teacher. In fact, they need the assistance of the teachers. Hence, learner autonomy does not mean learning without a teacher. In this process, teachers should be a guide for learners. These findings are in line with Thanasoulas (2000), Benson (2001) and Arshed (2015).

\subsubsection{Findings regarding the cultural universality of learner autonomy}

The teachers' conceptions about cultural universality of learner autonomy were collected by means of items 13 and 23. The following table presents the means and standard deviations of the responses to the items in this subsection.

Table7. The cultural universality of learner autonomy

\begin{tabular}{|l|l|l|}
\hline Statement & Mean & SD \\
\hline 13. Learner autonomy can be achieved by learners of all cultural backgrounds. & 3.76 & .964 \\
\hline 23. Learner autonomy is a concept which is not suited to non-Western learners. & 3.55 & .897 \\
\hline
\end{tabular}

As displayed in Table 7 , both items $(13,23)$ got the highest mean: 3.76, 3.55, respectively. This means that for most of the teachers, the cultural backgrounds of the learners are not considered to prevent them from developing autonomy. However, it might be inferred that they may consider autonomy as a concept that belongs to Western cultures. According to the interviews, some of the teachers are unsure whether or not this method is suitable for non-Western cultures.

\subsubsection{Findings regarding age and learner autonomy}

Teachers' beliefs on age and learner autonomy are illustrated in items 1, 10 and 20. These items are employed to discover what teachers think about the connection between age and learner autonomy.

Table8. Age and learner autonomy

\begin{tabular}{|l|l|l|}
\hline Statement & Mean & SD \\
\hline 1. Language learners of all ages can develop learner autonomy. & 3.95 & .825 \\
\hline 20. Learner autonomy is only possible with adult learners. & 3.78 & .756 \\
\hline $\begin{array}{l}\text { 10. It is possible to promote learner autonomy with both young language learners and with } \\
\text { adults. }\end{array}$ & 3.75 & .659 \\
\hline
\end{tabular}

As shown in Table 8, teachers expressed their opinions about age and learner autonomy. The results revealed that the highest mean was for item 1- "language learners of all ages can develop learner autonomy" - with a mean of 3.95 and standard deviation of .825.The next statement the teachers most agreed with was item 20, that "learner autonomy is only possible with adult learners", which had a mean of 3.78 and standard deviation of .756.Third was item 10, that "it is possible to promote learner autonomy with both young language learners and with adults", with a mean of 3.75 and standard deviation of .659. In other words, as can be drawn from the data, for most of the teachers, there is no age limitation in promoting learner autonomy; it is possible to become autonomous no matter how old learners are. The teachers do not differentiate between youths and adults in terms of developing autonomy. Salimi and Ansari (2015) also supported such a finding.

\subsubsection{Findings regarding proficiency and learner autonomy}

In this subsection, we examined the teachers' comments on the relation between proficiency and autonomy in regard to the three items $(9,26$ and 34). 
Table9. Proficiency and learner autonomy

\begin{tabular}{|l|l|l|}
\hline Statement & Mean & SD \\
\hline $\begin{array}{l}\text { 9. It is harder to promote learner autonomy with proficient language learners than it is with } \\
\text { beginners. }\end{array}$ & 3.85 & .997 \\
\hline $\begin{array}{l}\text { 26. Promoting autonomy is easier with beginning language learners than with more proficient } \\
\text { learners. }\end{array}$ & 2.96 & .972 \\
\hline 34. The proficiency of a language learner does not affect their ability to develop autonomy. & 2.90 & .989 \\
\hline
\end{tabular}

As can be seen in Table 9, the majority of the teachers indicated their agreement with item 9: "it is harder to promote learner autonomy with proficient language learners than it is with beginners". At the same time, nearly a third of them stated their agreement with items 26 and 34: "Promoting autonomy is easier with beginning language learners than with more proficient learners" and "The proficiency of a language learner does not affect their ability to develop autonomy", respectively. Thus, it is clear the teachers accepted that there is a connection between proficiency and learner autonomy. To some extent, they reported that proficient learners can develop autonomy more easily than the beginner learners. However, they thought that proficiency is not an issue that affects the development of autonomy. All learners can develop autonomy, no matter how proficient they are.

\subsubsection{Findings regarding learner-centredness and learner autonomy}

Here we investigated the teachers' opinions on the connection between learner autonomy and learner-centredness. The results are presented in Table 10 below.

Table10. Learner-centredness and learner autonomy

\begin{tabular}{|l|l|l|}
\hline Statement & Mean & SD \\
\hline 28. Learner-centred classrooms provide ideal conditions for developing learner autonomy. & 4.23 & 1.23 \\
\hline 15. Learner autonomy cannot be promoted in teacher-centred classrooms. & 3.37 & .983 \\
\hline 17. Learner autonomy implies a rejection of traditional teacher-led ways of teaching. & 2.30 & 1.34 \\
\hline
\end{tabular}

Table 10 shows that the majority of teachers agreed with item 28 , "learner-centred classrooms provide ideal conditions for developing learner autonomy", with a mean of 4.23 and standard deviation of 1.23. It is also clearly illustrated that most of the teachers expressed their agreement with item 15: "learner autonomy cannot be promoted in teacher-centred classrooms". On the other hand, the majority of the teachers showed that they disagreed with item 17, "learner autonomy implies a rejection of traditional teacher-led ways of teaching", with a mean of 2.30 and standard deviation of 1.34. Thus, from these results, it can be concluded that teachers have the common idea that the ideal classrooms for the development of autonomy are those that are learner-centred. So learner autonomy can be fostered more easily in such classrooms. In fact, it is very important to include learners in the learning process.

\subsubsection{Findings regarding benefits of learner autonomy for language learning}

This subsection presents the beliefs of the teachers about the benefits of learner autonomy for language learning by investigating their responses to items 5,12 and 36 .

Table11. The benefits of learner autonomy for language learning

\begin{tabular}{|l|l|l|}
\hline Statement & Mean & SD \\
\hline 36. Learner autonomy has a positive effect on success as a language learner. & 4.65 & .689 \\
\hline $\begin{array}{l}\text { 12. Learner autonomy allows language learners to learn more effectively than they otherwise } \\
\text { would. }\end{array}$ & 4.32 & .978 \\
\hline 5. Individuals who lack autonomy are not likely to be effective language learners. & 3.98 & .785 \\
\hline
\end{tabular}

Table 11 reveals that teachers shared the idea that learner autonomy has a positive effect on success. Additionally, they expressed their agreement on item 12, that "learner autonomy allows language learners to learn more effectively than they otherwise would". Moreover, the teachers believed that individuals who lack autonomy are not likely to be effective language learners. In short, the teachers agreed that learner autonomy offers a great contribution to the effective learning and success of language learners.

According to the interviews, the teachers' responses supported all the above results. In other words, the majority of the teachers have the common opinion that autonomy means being responsible of learning. They believe that only if learners take the responsibility for their own learning will they 
become autonomous. So autonomous learners can state their own needs and ways of learning. In fact, they have to take part in every aspect of learning. Moreover, teachers reported that learners who are autonomous are aware of the fact that learning is not limited to the classroom, so they can continue their learning outside the classroom. Thus, teachers work as guides for their learners. These findings concur with Borg and Al-Busaidi(2012) and Salimi and Ansari (2015).

\subsection{Teachers' Beliefs and Feelings about Autonomous Learners}

In the fourth part of the questionnaire, teachers were asked about the degree to which they feel their students are autonomous, and in the open-ended part of this question they were asked to write their comments on why they felt the way they did. Further, the researcher wanted them to describe autonomous language learners by answering the interview questions. Thus, this section presents the answer for the second research question: To what extent do teachers feel their learners are autonomous?

The questionnaire results showed that the majority of the teachers (39) thought their students were autonomous. On the other hand, 25 of them indicated the opposite, as the stated that they did not think that their students were autonomous, and only 12 teachers were unsure.

According to these findings, teachers seem to have different expectations of what autonomous learners were able to do, which was supported by their responses in the open-ended part of the question. The teachers' responses revealed that there are a number of reasons for the differences among teachers and their thoughts about autonomous learners. In other words, they pointed out they considered their students to be autonomous if they have at least some of the following: being aware of the weaknesses, strengths, and their own learning; having a right to comment on the learning process; making connections between language learning and the world at large; and, even more importantly, studying not only in the classroom but also in the language lab, in the resource centre and at home.

On the other hand, as mentioned above, 25 of the teachers demonstrated that they did not feel their students had a fair degree of autonomy. They explained their opinion by mentioning that their students lacked motivation for learning, relied too much on their teachers and always tried to be a way of taking responsibility. In addition, their students seem to be unaware of their weaknesses, strengths and their own learning.

The teachers' answers in the interviews are in line with these findings when they were asked about the general characteristics of autonomous language learners. They listed a number of the characteristics of autonomous language learners as they reported that such learners must be independent and have control over their learning. Further, they know how and when to study. They are generally motivated. So they can manage and evaluate their own learning in the learning process. This is consistent with Duong (2014) and Najmeh et al. (2015).

\subsection{Teachers' Beliefs and Feelings about the Role of Teachers in Promoting Learner Autonomy}

In this section, the answer for the third research question will be illustrated: To what extent do teachers say they actually promote learner autonomy? In order to learn the answer to this question, teachers were also asked in the fourth part of the questionnaire about the extent to which they feel they promote learner autonomy in their teaching. Teachers who felt they did promote learner autonomy were also asked in the open-ended part of the questionnaire to provide examples of the kind of strategies they used to do so.

The data obtained from the questionnaire revealed that the majority of the teachers ( 55 teachers out of 76) felt they give their students opportunities to develop autonomy in teaching English, 11 teachers were unsure and only 10 teachers disagreed. As seen in the open part of the questionnaire, the teachers reported that in order to promote learner autonomy they always give their students some tasks to be done outside of class. Further, they usually try to make conversation with the students individually. In the interviews, teachers said that they usually try to tell their students the importance and benefits of being autonomous, and they try to motivate them whenever they observe an autonomous behaviour. Moreover, teachers presented some strategies they used in order to develop autonomy, such as asking their students about the teaching methods or activities they prefer. It can be concluded that the teachers seem to have a favourable impression of autonomy, and they usually try and work hard to promote it in order to have more successful language learners. Such findings are in line with previous studies such as Benson (2000), Huang (2006), Joshi (2011) and Borg and Al-Busaidi (2012). 


\subsection{Teachers' Beliefs and Feelings about the Desirability and Feasibility of Promoting Learner Autonomy}

The fourth research question,- - How desirable and feasible do teachers feel it is to promote learner autonomy? - will be addressed in this section. The teachers' responses to this question were explored by means of the third section of the questionnaire. This section consists of two issues, the first being teachers' views on the desirability and feasibility of involving learners in a range of language course decisions. The second issue is teachers' views of how desirable and feasible they felt it was for their students to develop a range of abilities that are commonly seen as indicators of learner autonomy.

\subsubsection{Desirability and feasibility of student involvement in decision-making}

The results regarding teachers' views of the desirability and feasibility of students' involvement in decision-making are summarized in Table 12 below. At first glance, it was noted that the teachers were more positive about the desirability of students' involvement than they were about the feasibility.

Table12. Desirability and feasibility of students' involvement in decision-making

\begin{tabular}{|l|l|l|l|l|}
\hline Items & \multicolumn{3}{l|}{ Fesirability } & \multicolumn{2}{l|}{ Feasibility } \\
\cline { 2 - 5 } Learners are involved in decisions about: & Mean & SD & Mean & SD \\
\hline 1. The objectives of a course. & 3.14 & .834 & 2.33 & .789 \\
\hline 2. The material used. & 3.20 & .879 & 2.37 & .753 \\
\hline 3. The kinds of tasks and activities they do. & 3.23 & .692 & 2.80 & .815 \\
\hline 4. The topics discussed. & 3.40 & .745 & 2.95 & .879 \\
\hline 5. How learning is assessed. & 2.83 & .878 & 2.21 & .831 \\
\hline 6. The teaching methods. & 2.98 & .825 & 2.59 & .765 \\
\hline 7. Classroom management. & 3.16 & .766 & 2.68 & .759 \\
\hline
\end{tabular}

Table 12 reveals that students' involvement in decision-making was seen to be most desirable in relation to topics, activities and material, while it was least desirable in relation to assessment, teaching methods, classroom management and objectives of a course. Moreover, according to teachers' views about feasibility in decision-making, and as shown in Table 12, students' involvement in decision-making was seen to be most feasible in relation to topics, activities and classroom management. However, they were least feasible in assessment, objectives of a course and material used. Duong (2014) and Salimi and Ansari (2015) supported such a finding.

\subsubsection{Desirability and feasibility of "learning-to-learn" skills in students}

In this section, a comparison of teachers' views on how desirable and feasible they felt it was for their students to develop a range of abilities is presented. As can be seen in Table 13 below, desirability was clearly viewed as higher than feasibility.

Table13. Desirability and feasibility of "learning-to-learn" skills in students

\begin{tabular}{|l|l|l|l|l|}
\hline Items & \multicolumn{2}{l|}{ Desirability } & \multicolumn{2}{l|}{ Feasibility } \\
\cline { 2 - 5 } Learners have the ability to: & Mean & SD & Mean & SD \\
\hline 1.Identify their own need. & 3.42 & .923 & 2.64 & .977 \\
\hline 2.Identify their own strengths. & 3.50 & .842 & 2.70 & .969 \\
\hline 3.Identify their own weaknesses. & 3.48 & .877 & 2.36 & .945 \\
\hline 4.Monitor their progress. & 3.44 & .998 & 2.57 & .893 \\
\hline 5. Evaluate their own learning. & 3.39 & .987 & 2.55 & .925 \\
\hline 6.Learn co-operatively. & 3.61 & .899 & 3.24 & .879 \\
\hline 7.Learn independently. & 3.58 & .979 & 3.11 & .967 \\
\hline
\end{tabular}

As displayed in Table 13, the results showed that learning co-operatively, learning independently and identifying their own strengths were reported to be most desirable skills for students. On the other hand, evaluating students' own learning, identifying their own needs and monitoring their progress were considered to be the least desirable skills. Further, in terms of feasibility, learning cooperatively, learning independently and identifying their own strengths were seen to be the most feasible skills for learners, whereas identifying their own weaknesses, evaluating their own learning and monitoring their own progress were the least feasible skills. Such findings are in line with the teachers' answers in the interviews when they were asked about their opinions on students' involvement in the decision-making process. This is consistent with Borg and Al-Busaidi (2012). 
According to the teachers' responses in the interviews, the results revealed that the majority of the teachers have the same idea of not allowing the students to be involved in the decision-making process for course objectives, materials and curriculum. The teachers explained that they thought their students were not proficient enough to decide on these subjects. They did not altogether ignore the students' role in decision-making, but rather they preferred the students be involved in choosing the tasks and activities used in class.

\subsection{Teachers' Challenges in Helping Learners to Become More Autonomous}

This section investigates the teachers' opinions about the challenges they face in order to help their learners become more autonomous, as a way to answer the fifth research question: What challenges do teachers face in helping their learners become more autonomous? In order to answer this question, teachers were asked in the interviews to point out the challenges they felt they faced in developing autonomy in learners. According to the teachers' responses in the interviews, a number of challenges can be listed:

1. Learners' lack of motivation in learning language, as their main aim was to pass the course.

2. Learners' different expectations, needs and learning styles.

3. Learners' lack of understanding the importance of developing autonomy.

4. Learners' lack of previous experience of autonomous learning.

5. Learners' lacking the skills to learn independently.

6. Learners' lack of responsibility for their learning.

7. Learners' dependence on teacher.

8. Limited learner contact with English outside the classroom.

9. Limited learner proficiency in English.

10. Limited time for the class.

11. Lack of relevant resources for teachers and learners.

12. Teachers' limited expectations of what learners can achieve.

13. Teachers' fear of losing control.

Such findings were supported by previous studies, including Little et al. (1998), Reinders and Lazaro (2011) and Borg and Al-Busaidi (2012).

\section{Conclusion}

This study aimed to explore teachers' beliefs about learner autonomy. Through a survey questionnaire and interview questions, the results reveal that teachers are positive to the concept of autonomy and its advantages for language learners. The majority of them are in favour of promoting autonomy by including students in decision-making and different activities inside and outside the classroom during the learning process, as well as having students take responsibility for their own learning. They defined learner autonomy as responsibility, control, self-observation, choice, motivation and decision. They believe that learner autonomy has a positive effect on the success of language learners and that autonomous learners learn more effectively. In addition, the main characteristics of autonomous learners identified by the teachers were responsible, controller, active, motivated and efficient. This agrees with the findings of Al-Shaqsi (2009).

Moreover, regarding the desirability and feasibility of the two issues related to decision-making and learners' abilities, the results show that there is a remarkable gap between the extent to which teachers felt it desirable to involve learners in either the range of decisions about their learning or the range of abilities associated with autonomy, on the one hand, and their feasibility of doing so, on the other. Such findings are supported by Durmus (2006) and Borg and Al-Busaidi (2012). Additionally, teachers stated that learners should be given opportunities to set goals and objectives for their learning process, and they supported the idea of giving learners the responsibility to choose topics and activities. Further, teachers had different opinions regarding the extent to which their learners were autonomous. In other words, teachers who thought their students were autonomous listed the characteristics as being aware of their own weaknesses, strengths and learning as well as having the right to comment on the learning process. On the other hand, lack of motivation; too much dependence on teachers; unwillingness to take responsibility; and being unaware of their own 
weaknesses, strengths and learning were some of the factors teachers believed contributed to what they saw as a lack of autonomy in their students. They concluded that in order to promote autonomy, learners should be given the chance to provide their opinions in the learning process.

\section{Pedagogical implications}

In conclusion, we believe that in order for teachers to promote learner autonomy, they should first be aware of the importance of learner autonomy so that they can help students gradually become independent learners. Secondly and importantly, they themselves should have a degree of autonomy in managing their courses. Non-autonomous teachers should be provided with training on how to be autonomous. Also, teacher educators must familiarize the trainees with the concept of learner autonomy and try to equip them with the best strategies for promoting autonomy. In addition, teachers need to improve their knowledge about the learning process and not be resistant to new approaches. Teachers should also get a better understanding of the levels of learner autonomy, so they can determine what degree students can possibly assume. Then they can help students to develop their autonomy. Additionally, teachers should be able to evaluate their students' needs and identify their learning preferences and learning independently as all students possess different learning styles. Thus, teachers have to prepare a variety of learning resources that can cater to students' diverse learning styles. Moreover, education programmes for teachers and students need to provide opportunities and training for both teachers and students on how to promote learner autonomy in their teaching and learning. Also, special programmes and courses related to autonomous language learning should be given to teachers from time to time to keep them up to date in order to practice and improve autonomous teaching and learning. Additionally, administrators should organize seminars or training sessions about learner autonomy for both teachers and students.

\section{Limitations of the study}

With regard to the results of this study, the following are some limitations to be taken into account:

1. The number of participants was not big enough, so the sample size should be increased.

2. The participants were from only one university in Saudi Arabia, so it would be better if they were chosen from different universities.

3. Various factors were not included in this study, such as age, gender and years of experience in teaching.

4. Questionnaire and interview were the only research methods used in this study.

\section{Suggestions for further research}

There are a number of suggestion that might be taken in consideration for further research:

1. This study was conducted with the teachers working at Aljouf University. A further study can be also conducted at other universities in Saudi Arabia, and different variables regarding teachers that might influence learner autonomy - such as age, gender, different backgrounds and years of experience - could be taken into account.

2. Moreover, a further study can also be conducted with students to determine their opinions toward the promotion of learner autonomy in the same setting. Thus, the opinions of the teachers and students can be compared.

3. Questionnaire and interview are the methods used to collect data in this study, yet it would be useful if a further study used other methods such as observation. In other words, a further study can be conducted to determine the practices of teachers in promoting learner autonomy by observing their classroom applications.

\section{REFERENCES}

Al Asmari, A. (2013). Practices and prospects of learner autonomy: Teachers' perceptions. English Language Teaching, 6(3), (pp. 1-10).

Al-Shaqsi, T. (2009). Teachers' beliefs about learner autonomy. In Borg, S. (Ed.), Researching English language teaching and teachers development in Oman (pp. 157-165). Muscat: Ministry of Education, Oman.

Balcikanli, C. (2010). Learner autonomy in language learning: Student teachers' beliefs. Australian Journal of Teacher Education, 35(1), (pp.90-103). 
Benson, P. (2000). Autonomy as learners' and teachers' right. In Sinclaire, B, McGrath, I., and Lamb, T. (Eds.), Learner autonomy, teacher autonomy: Future directions (pp. 111-117). Harlow: Pearson Education.

Benson, P. (2001). Teaching and researching autonomy in language learning.Harlow: Pearson Education.

Benson, P. (2006). Autonomy in language teaching and learning. Language Teaching, 40(1), (pp. 21-40).

Benson, P. (2008). Teachers' and learners' perspectives on autonomy. In Lamb, T., and Reinders, H. (Eds.), Learner and teacher autonomy: Concepts, realities, and responses. Amsterdam/ Philadelphia: John Benjamins, (pp.15-23).

Benson, P. (2011). Teaching and researching autonomy in language learning ( $\left.2^{\text {nd }} e d.\right)$. Harlow: Longman.

Benson, P., and Voller, P. (1997). Autonomy and independence in language learning. London: Longman.

Borg, S., and Al-Busaidi, S. (2012). Learner autonomy: English language teachers' beliefs and practices. London: British Council.

Barillaro, F. (2011). Teacher perspectives of learner autonomy in language learning MA dissertation. TESOL Centre. Sheffield Hallam University.

Benson, P and Toogood, S. (2008). Learner Autonomy 7: Challenges to research and practice. Dublin: Authentik

Crabbe, D. (1993).Fostering autonomy from within the classroom: The teacher's responsibility. System, 21 (4), 443-52

Camilleri, G. (1997). Learner autonomy: The teachers' views. Strasbourg: Council of Europe Publishing.

Camilleri, G. (Ed.). (1999). Learner autonomy: The teachers' views. Strasbourg: Council of Europe Publishing.

Camilleri, G. (2007). Pedagogy for autonomy, teachers' attitudes and institutional change: A case study. In Raya, M., and Sercu, L. (Eds.), Challenging in teacher development: Learner autonomy and intercultural competence (pp. 81-102). Frankfurt: Peter Lang.

Chan, V. (2001). Readiness for learner autonomy: What do our learners tell us? Teaching in Higher Education, 6(4), (pp.505-519).

Chan, V. (2003). Autonomous language learning: The teachers' perspectives. Teaching in Higher Education, 8(1), (pp. 33-54).

Cotterall, S. (1995). Readiness for autonomy: Investigating learner beliefs. System, 23(2), (pp. 195-205).

Crabbe, D. (1993). Fostering autonomy from within the classroom: The teachers' responsibility. System, 21(4), (pp. 443-452).

Dam, L., Eriksson, R., Little, D., Miliander, J., and Trebbi, T. (1990). Toward a definition of autonomy. In Trebbi, T. (Ed.), Third Nordic workshop on developing autonomous learning in the EFL classroom, (pp. 102-113). Bergen: University of Bergen.

Dickinson, L. (1987). Self-Instruction in language learning. Cambridge: Cambridge University Press.

Dickinson, L. (1994). Talking shop: Aspects of autonomous learning, An interview with Leslie Dickinson. ELT Journal, 47(1), (pp. 330-341).

Duong, T. (2014). EFL teachers' perceptions of learner autonomy and their classroom practices: A case study. I. J. Education and Management Engineering, 2, (pp. 9-17).

Dam, L. (1995). Learner Autonomy 3: From Theory to Classroom Practices. Dublin: Authentik

Durmus, A. (2006). EFL Instructors' Perceptions on Learner Autonomy at Anadolu University. MA thesis, Anadolu University: Eskisehir.

Freire, P. (1996). Pedagogy of the oppressed. London: Penguin.

Guest, G. (2012). Applied Thematic Analysis. Thousand Oaks, California: Sage.

Hedge, T. (2000). Teaching and learning in the language classroom. Oxford: Oxford University Press.

Holec, H. (1981). Autonomy and foreign language learning. Oxford: Pergamon: Strasbourg: Council of Europe. 
Huang, J. (2006). Fostering learner autonomy within constraints: Negotiation and mediation in an atmosphere of collegiality. Prospect: An Australian Journal of TESOL, 2(3), (pp. 38-57).

Joshi, K. (2011). Learner perceptions and teacher beliefs about learner autonomy in language learning. Journal of NELTA. 16(12), (pp. 13-29).

Kenny, B. (1993). For more autonomy. System, 21(4), (pp. 431-442).

Little, D. (1991). Learner autonomy: Definitions, issues and problems. Dublin: Authentik.

Little, D. (1995). Learning as dialogue: The dependence of learner autonomy on teacher autonomy. System, 23(2), (pp. 175-182).

Little, D., Dam, L., and Timmer, J. (1998). Focus on learning rather than teaching: Why and how? Paper from the International Association of Teachers of English as a Foreign Language (IATEFL) Conference. (pp. 38-56).

Little, D., Dam, L., and Timmer, J. (2007). Preparing teachers to use the European language portfolio: Arguments, materials and resources. Council of Europe: Council of Europe Publishing.

Littlejohn, A. (1985). Learner choice in language study. ELT Journal, 39(4), (pp. 253-261).

Littlewood, W. (1999). Defining and developing autonomy in East Asian context. Applied Linguistics, 20(1), (pp. 71-94).

Murphy, L. (2008). Supporting learner autonomy: Developing practice through the production of courses for distance learner of French, German and Spanish. Language Teaching Research, 12(1), (pp.83-102).

Najmeh, N., Abbas, E., Hossein, V., and Zahra, A. (2015). Promoting learner autonomy in an Iranian EFL high school context: Teachers' practices and constraints in focus. International Journal of Research Studies in Language Learning, 4(3), (pp. 91-105).

Nakata, Y. (2011). Teachers' readiness for promoting learner autonomy: A study of Japanese EFL high school teachers. Teaching and Teacher Education, 27(5), (pp.900-910).

Nunan, D. (1997). Designing and Adapting Materials to Encourage Learner Autonomy. In Benson, P. and Voller, P. (Eds) Autonomy and Independence in Language Learning. London: Longman. (pp. 192-203)

Reinders, H., and Lazaro, N. (2011). Beliefs, identity and motivation in implementing autonomy: The teachers' perspectives. In Murray, G., Gao, X., and Lamb, T. (Eds.), Identity, motivation, and autonomy in language learning (pp. 125-142). Bristol: Multilingual Matters.

Sadeghi, S. (2012). A critical reflection on the high-stake test effects: Toward a local model for teacher professionalism. Unpublished $\mathrm{PhD}$ dissertation, University of Isfahan, Isfahan, Iran.

Salimi, A., and Ansari, N. (2015). Learner autonomy: Investigating Iranian English teachers' beliefs. Theory and Practice in Language Studies, 5(5), (pp. 1106-1115).

Smith, R. (2008). Learner autonomy (Key concepts in ELT). ELT Journal, 62(4), (pp. 395-397).

Thanasoulas, D. (2000). What is learner autonomy and how can it be fostered? Internet TESL Journal, 6, (pp. 1-11).

Yildirim, O. (2008). A study on a group of Indian English as a second language: Learners' perceptions of autonomous learning. Turkish Online Journal of Qualitative Inquiry, 3(2), (pp. 18-29).

Young, R. (1986). Personal autonomy: Beyond negative and positive liberty. London: Croom Helm.

Yunus, M., and Arshad, N. (2015). ESL teachers' perceptions toward the practices and prospects of autonomous language learning. Asian Social Science, 11(2), (pp. 41-51).

Zhuang, J. (2010). The changing role of teachers in the development of learner autonomy. Journal of Language Teaching and Research, 1(5), (pp. 591-595).

\section{AUTHOR's BIOGRAPHY}

Maha Alhaysony, holds a $\mathrm{PhD}$ in applied linguistics from University of Essex in UK. She is an associate professor of applied linguistics at the Department of English at the University of Ha'il, Saudi Arabia. She has been teaching English for more than 15 years. Her main research interests are second language acquisition, second language writing, language learning strategies, vocabulary learning strategies, learner autonomy and lexicography. 